\title{
Effect of Poultry Manure and Phosphorous on Phenology, Yield and Yield Components of Wheat
}

\author{
Muhammad Faheem Jan ${ }^{1 *}$, Muhammad Dawood Ahmadzai ${ }^{1}$, \\ Waqas Liaqat ${ }^{1}$, Haseeb Ahmad ${ }^{1}$ and Wazir Rehan ${ }^{2}$ \\ ${ }^{1}$ Department of Agronomy, The University of Agriculture Peshawar, Pakistan \\ ${ }^{2}$ Agricultural Research Institute Tarnab Peshawar, Pakistan \\ *Corresponding author
}

\section{A B S T R A C T}

Soil phosphorous (P) limitation is one of the most important obstructions to food production in Pakistan. An experiment was carried out at Agronomy research farm of the

Keywords

Tillers $\mathrm{m}^{-2}$, Spike length, Thousand grain weight, Biological yield

\section{Article Info}

Accepted:

30 April 2018

Available Online:

10 May 2018
University of Agriculture, Peshawar during winter 2015 with an objective to estimate the effect of poultry manure (PM) and P on wheat performance. Experiment was laid out in randomized complete block design having four replications. Three levels of PM (1, 1.5, 2 tons $\left.\mathrm{ha}^{-1}\right)$ and five levels of $\mathrm{P}\left(0,50,75,100\right.$ and $\left.125 \mathrm{~kg} \mathrm{ha}^{-1}\right)$ were taken as treatments. Poultry manure and $\mathrm{P}$ significantly affected phenology, yield and yield components of wheat. More tillers $\mathrm{m}^{-2}$ with maximum days to anthesis, maturity and maximum spike length, grains spike ${ }^{-1}$, thousand grains weight, biological yield and grain yield were recorded in plots treated with PM @ of 2 tons ha $^{-1}$. With increase in P levels days to anthesis and maturity decreased. Maximum tillers $\mathrm{m}^{-2}$, spike length, grains $\mathrm{spike}^{-1}$, thousand grain weight and grain yield was recorded for P applied @ of $125 \mathrm{~kg} \mathrm{ha}^{-1}$ which was statistically similar to P applied @ of $100 \mathrm{~kg} \mathrm{ha}^{-1}$. Maximum biological yield was recorded with the application of $125 \mathrm{~kg} \mathrm{P} \mathrm{ha}^{-1}$. Based on the experimental results it can be concluded that application of PM @ of 2 tons ha ${ }^{-1}$ in combination with P @ of $100 \mathrm{~kg} \mathrm{ha}{ }^{-1}$ resulted in higher productivity of wheat.

\section{Introduction}

Wheat is staple diet of communities living in Pakistan. In order to continue its adequate supply, it is mandatory to improve per acre yield of the crop. Among the plant nutrients, Phosphorus (P) is critical to improve the yield of wheat as over $90 \%$ soils in Pakistan are low in available $\mathrm{P}$ (Ahmed et al., 1992). Moreover, with the passage of time, the adsorption of $\mathrm{P}$ gets firmer thus creating difficulties in release to soil solutions. Consequently, efficiency of fertilizer $\mathrm{P}$ in calcareous soils remains comparatively low (Delgado et al., 2002). There is need to make $\mathrm{P}$ fertilizer recommendations site specific as well as crop specific on scientific basis (Ahmed et al., 1992). Wheat roots absorb $\mathrm{P}$ only from the soil solution (Johnston et al., 1999). Despite its higher yield potential, yield per hectare is very low in Pakistan as compared to other wheat producing countries (Sarwar et al., 2010). There are many reasons 
of low yield but the most important is the injudicious use of phosphorus fertilizer. Phosphorus fertilization is very essential for exploitation of good yield of different crops (Rashid et al., 1994). Phosphorus plays a vital role in several physiological processes viz photosynthesis, respiration, energy storage and cell division/ enlargement. It is also a structural component of many biochemical processes via nucleic acid (DNA and RNA enzymes and coenzymes) and also stimulates root growth and associated with early maturity of crops. Phosphorous is one of the most limiting plant nutrients in cropping system across the world (Shenoy and Kalagudi, 2005). $P$ is unavoidable for Agriculture (Osava, 2007).

Optimum amount of $\mathrm{P}$ is necessary for higher yield, crop quality with healthy stalk growth, root growth and to get earlier maturity (Bugbee and Khera, 1999). Effectiveness and efficiency of $\mathrm{P}$ is more when applied at sowing (Rehman et al., 2007). Presently the challenges faced by the researchers are to increase yield, decrease the cost of production and improve soil health.

To overcome these challenges, they have to consider combined use of natural and synthetic fertilizers, organic farming and timing of nutrients application (Huang et al., 2007; Rasool et al., 2007). In Pakistan, cost of fertilizers particularly phosphatic is increasing and most of the farmers are poor. This situation demands to determine some approaches through which efficiency of small amount of fertilizers added to the soil are improved (Twyford, 1994).

Nowaday's farmers are moving to add natural fertilizers to the soil for sustainable yield (Naeem et al., 2009). Combined use of natural wastes (manures) and synthetic fertilizers can be a better way to maintain soil nutrient status and to promote sustainability in crop production (Paul and Mannan, 2006). Integration of organic manures with synthetic fertilizers improves soil physical properties (bulk density, porosity, compaction), chemical properties (soil $\mathrm{pH}$, carbon sequestration, organic $\mathrm{N}$ and $\mathrm{P}$ ) and ultimately the crop yield (Rautaray et al., 2003). An economical and effective approach to achieve sustainability in crop production system is the simultaneous use of organic and synthetic fertilizers (Gosh et al., 2004). Application of $\mathrm{P}$ from natural fertilizers has almost same or better effect than applied from synthetic fertilizers.

Poultry manure $(\mathrm{PM})$ is a rich source of macro $(\mathrm{N}, \mathrm{P}, \mathrm{K})$ and micro $(\mathrm{S}, \mathrm{Fe})$ nutrients and also has a better effect on soil health (Sims and Wolf, 1994). It serves as an organic matter for the soil, improves soil biological life and enhanced soil water holding capacity (Deksissa et al., 2008). Mineralization of PM is higher than other natural manures (cattle, pig) thus it readily releases its nutrients when added to the soil for plant uptake (Brady and Weil, 1999). Sharply and Smith (1991) indicated that crop yield significantly improved with the addition of PM because it contains basic nutrients necessary for healthy crop growth. Application of poultry manure increases carbon content, water holding capacity, aggregation of soil, and decreases bulk density (Egerszegi, 1990). P availability of PM to plants is more and quicker than other natural manure (Garg and Bahla, 2008).

\section{Materials and Methods}

\section{Experimental site}

The experimental site $\left(34^{\circ} 00^{\prime} 43.2^{\prime \prime} \mathrm{N}\right.$ $\left.71^{\circ} 28^{\prime} 00.4^{\prime \prime E}\right)$ was Agronomy Research Farm of the University of Agriculture Peshawar, Pakistan. Peshawar is located at $34 \mathrm{oN}$ latitude, $71 \mathrm{oE}$ longitude with an altitude of $350 \mathrm{~m}$ above sea level and has a sub-tropical climate. Soil description 
Soil of experimental site was alkaline $(\mathrm{pH}$ 8.02 ) and calcareous in nature, low in organic matter $\left(0.845 \mathrm{~g} \mathrm{~kg}^{-1}\right)$, non-saline (EC (1:1) $\left.0.87 \mathrm{~d} \mathrm{~S} \mathrm{~m}^{-1}\right)$, low in available nitrogen $(0.04 \mathrm{~g}$ $\mathrm{kg}^{-1}$ ) and phosphorous $\left(4 \mathrm{mg} \mathrm{kg}{ }^{-1}\right)$ with near sufficient in potassium $\left.(80 \mathrm{mg} \mathrm{kg})^{-1}\right)$. The texture of the soil was silty clay loam having $40 \%$ clay, $51.3 \%$ silt and $8.7 \%$ sand. Canal water was available for irrigation (Saleem et al., 2015).

\section{Experimental details}

The experiment was designed in randomized complete block design (RCBD) with split plot arrangement keeping three replications. A sub plot size was $18 \mathrm{~m}^{2}$ including 6 rows, $4 \mathrm{~m}$ long and $0.75 \mathrm{~m}$ apart. Wheat variety (SIRAN) was sown with30 kg ha ${ }^{-1}$ seed rate. The treatments consisted of three levels of poultry manure (1, 1.5 and 2 tons $\left.\mathrm{ha}^{-1}\right)$ and four levels of $\mathrm{P}(50$, 75,100 and $125 \mathrm{~kg} \mathrm{ha}^{-1}$ ). A control treatment was also included in the experiment. Poultry manure was applied two weeks before sowing and full Phosphorus dose was applied during seedbed preparation. Ploughing of field was done when proper field capacity level was reached with cultivator directly followed by rotavator. Field was irrigated when needed considering the weather conditions particularly rainfall. All cultural practices carried out for better crop growth and development were kept same to all treatments.

\section{Procedure for recording data}

Data regarding tillers $\mathrm{m}^{-2}$ was calculated by counting the number of tillers in two central rows of each plot and converted into tillers $\mathrm{m}^{-2}$. Days to anthesis was recorded from sowing till date when anthers appeared in $80 \%$ plants in each subplot. Days to maturity were recorded by counting the number of days from sowing to date when $80 \%$ plants showed maturity symptoms in each sub plot. Spike length of ten spikes randomly selected in each plot was measured from base of first spikelet to the tip of terminal spikelet excluding awn and was averaged for mean spike length $(\mathrm{cm})$. Ten spikes were randomly selected in each plot; their grains were counted and averaged. Biological yield was calculated by harvesting four middle rows in each plot, tied into bundles, sun dried, and weighed to determine biological yield. Cleaned thousand grains were randomly taken from each treatment and weighed on electronic balance to determine its weight. Four central rows harvested for biological yield were threshed, cleaned, and weighed to estimate grain yield. The data was converted into $\mathrm{kg} \mathrm{ha}^{-1}$.

\section{Statistical analysis}

The recorded data was statistically analyzed using the procedure outlined by Jan et al., (2009) for RCB design. Upon significant Ftest, means were compared using least significant difference (LSD) test at $\mathrm{P} \leq 0.05$.

\section{Results and Discussion}

\section{Tillers $\mathbf{m}^{-2}$}

Poultry manure (PM) and Phosphorus (P) levels significantly affected tillers $\mathrm{m}^{-2}$ (Table 1). The interaction of $P M$ and $P$ levels was found non-significant for tillers $\mathrm{m}^{-2}$. Mean effect of $\mathrm{P}$ levels indicated that highest tillers $\mathrm{m}^{-2}$ was recorded in plots which was treated with PM@ of $2 \mathrm{t} \mathrm{ha}^{-1}$ while lowest tillers $\mathrm{m}^{-2}$ was recorded in plots treated with 1 ton $\mathrm{ha}^{-1}$ PM. Enujeke (2013) reported that application of poultry manure increased plant growth because more nutrients were made readily available and easily absorbable by receiving plants leading to faster growth and development and ultimately to more tillers $\mathrm{m}^{-2}$. Our findings are supported by Ibrahim et al., (2008). Means of P levels showed that highest tillers $\mathrm{m}^{-2}$ was recorded in plots treated with $125 \mathrm{~kg} \mathrm{ha}^{-1} \mathrm{P}$ which was statistical similar with $100 \mathrm{~kg} \mathrm{ha}^{-1} \mathrm{P}$ while lowest tillers 
$\mathrm{m}^{-2}$ was recorded in $50 \mathrm{~kg} \mathrm{ha}^{-1} \mathrm{P}$ treated plots. Increase in growth parameters in different crops while increasing $\mathrm{P}$ rate is earlier reported in many studies from different parts of the world (Opala et al., 2009; Rast et al., 2010; Rasavel and Ravichandran, 2013). Fageria et al., (2003) and Fageria and Baligar (2005) reported that tillering capacity was considerably affected by $\mathrm{P}$ application.

Our results are supported by Tahir et al., (2004) who documented that $\mathrm{P}$ application increase tillers $\mathrm{m}^{-2}$ in wheat crop. Significant difference was recorded in control vs rest plots for tillers $\mathrm{m}^{-2}$.

\section{Days to anthesis}

Days to anthesis of wheat crop as affected by poultry manure and phosphorus levels is reported in Table 1. Statistical analysis of the data revealed that poultry manure had no significant effect on days to anthesis while phosphorus levels significantly affected days to anthesis. Interaction of poultry manure and phosphorus remained non-significant for days to anthesis. Planned mean comparison showed that early anthesis was observed in plots which were treated with $\mathrm{P}$ at the rate of $125 \mathrm{~kg}$ ha $^{-1}$ which was statistically non-significant with $100 \mathrm{~kg} \mathrm{ha}^{-1} \mathrm{P}$ treatment while delayed anthesis was observed in $50 \mathrm{~kg} \mathrm{ha}^{-1} \mathrm{P}$ treatment. The increased rate of Phenological development with increasing $\mathrm{P}$ fertilization has been seen in other studies on different crops (Amanullah and Khan, 2010; Khalil et al., 2010; Amanullah and Khalid, 2015). As P deficiency decrease both root and shoot development (Amanullah and Stewart, 2013) and phosphorus uptake (Amanullah and Inamullah, 2016b), which causes a delay in phonological development (Amanullah et al., 2014; Amanullah and Khalid, 2015). Significant difference was recorded in control vs rest for days to anthesis.

Days to maturity
Data pertaining days to maturity of wheat crop as influenced by poultry manure and phosphorus levels are presented in Table 1. Statistical analysis of data showed that PM and $\mathrm{P}$ levels significantly affected days to maturity. Interaction of PM and P levels remained non-significant for days to maturity. Mean effect of PM levels showed that more days to maturity was observed in plots which was treated with PM @ of $2 \mathrm{t} \mathrm{ha}^{-1}$ while less days to maturity was observed for $1 \mathrm{t} \mathrm{ha}^{-1} \mathrm{PM}$. It might be due to high content of essential nutrients present in poultry manure which accelerates vegetative growth and delays maturity.

Our results are in line with Dannis et al., (2002) who reported that poultry manure have high content of essential nutrients as compared to others organic sources and accelerate vegetative growth when applied at sowing time leading to late maturity. Planned mean comparison of $\mathrm{P}$ levels indicated that early maturity was observed in $125 \mathrm{~kg} \mathrm{ha}^{-1}$ phosphorus plot which was statistical at par with $100 \mathrm{~kg} \mathrm{ha}^{-1}$ phosphorus plot while delayed maturity was observed in $50 \mathrm{~kg} \mathrm{ha}^{-1}$ phosphorus plot. This might be due to the reason that $\mathrm{P}$ application improved root growth which enhanced nutrients uptake and resulted in early maturity. Root and shoot development with $\mathrm{P}$ uptake decreased with $\mathrm{P}$ deficiency (Amanullah and Stewart, 2013) which might cause a delay in Phenological development (Amanullah et al., 2014; Amanullah and Khalid, 2015; Amanullah et al., 2016b). Control vs rest plots showed significant difference for days to maturity.

\section{Spike length (cm)}

Data regarding spike length of wheat crop as affected by poultry manure and phosphorus levels are reported in Table 2. 
Table.1 Tiller $\mathrm{m}^{-2}$, days to anthesis and maturity of wheat crop as affected by poultry manure and Phosphorus levels

\begin{tabular}{|c|c|c|c|}
\hline Treatment & Tiller $\mathrm{m}^{-2}$ & Days to anthesis & Days to maturity \\
\hline \multicolumn{4}{|c|}{ Poultry Manure(tons ha ${ }^{-1}$ ) } \\
\hline 1 & $264 \mathrm{~b}$ & 135 & $166 \mathrm{~b}$ \\
\hline 1.5 & $268 \mathrm{~b}$ & 135 & $164 \mathrm{c}$ \\
\hline 2 & $278 \mathrm{a}$ & 135 & $167 \mathrm{a}$ \\
\hline $\begin{array}{c}\text { LSD (0.05) } \\
\end{array}$ & 8 & Ns & 0.95 \\
\hline \multicolumn{4}{|c|}{ Phosphorus Levels $\left(\mathrm{kg} \mathrm{ha}^{-1}\right)$} \\
\hline $\begin{array}{c}50 \\
\end{array}$ & $260 \mathrm{~b}$ & $135 \mathrm{a}$ & $164 \mathrm{a}$ \\
\hline 75 & $267 \mathrm{~b}$ & $134 \mathrm{~b}$ & $164 \mathrm{a}$ \\
\hline 100 & $275 \mathrm{a}$ & $131 \mathrm{c}$ & $161 \mathrm{~b}$ \\
\hline 125 & $280 \mathrm{a}$ & $131 \mathrm{c}$ & $161 \mathrm{~b}$ \\
\hline LSD(0.05) & 7.3 & 0.92 & 0.86 \\
\hline Control & 255 & 137 & 169 \\
\hline Rest & 270.28 & 134 & 164 \\
\hline Interaction & Ns & Ns & Ns \\
\hline
\end{tabular}

Means sharing same letter(s) for a parameter in a column are statistically similar at 5\% level of significance. ns= non-significant

Table.2 Spike length $(\mathrm{cm})$, grains spike ${ }^{-1}$, thousand grains weight $(\mathrm{g})$, biological yield $\left(\mathrm{kg} \mathrm{ha}^{-1}\right)$ and grain yield $\left(\mathrm{kg}^{-1}\right)$ of wheat $\mathrm{crop}$ as influenced by poultry manure and phosphorus levels

\begin{tabular}{|c|c|c|c|c|c|}
\hline Treatment & Spike length (cm) & Grains spike $^{-1}$ & $\begin{array}{l}\text { Thousand grain weight } \\
\text { (g) }\end{array}$ & Biological yield $\left(\mathrm{kg} \mathrm{ha}^{-1}\right)$ & $\begin{array}{c}\text { Grain yield } \\
\left(\mathrm{kg} \mathrm{ha}^{-1}\right)\end{array}$ \\
\hline \multicolumn{6}{|c|}{ Poultry Manure(tons $\mathrm{ha}^{-1}$ ) } \\
\hline 1 & $9.52 \mathrm{~b}$ & $45 \mathrm{~b}$ & $41.55 \mathrm{~b}$ & $8690 \mathrm{~b}$ & $3115 b$ \\
\hline 1.5 & $9.95 \mathrm{a}$ & $46 \mathrm{~b}$ & $43.45 \mathrm{a}$ & $9022 \mathrm{a}$ & $3540 a$ \\
\hline 2 & $10.2 \mathrm{a}$ & $49 a$ & $44.56 \mathrm{a}$ & $9280 \mathrm{a}$ & $3655 a$ \\
\hline $\begin{array}{l}\text { LSD }(0.05) \\
\end{array}$ & 0.4 & 2.5 & 1.7 & 325.8 & 246.6 \\
\hline \multicolumn{6}{|c|}{ Phosphorus Levels $\left(\mathrm{kg} \mathrm{ha}^{-1}\right)$} \\
\hline 50 & $9.45 \mathrm{~b}$ & $46 \mathrm{~b}$ & $40.15 \mathrm{c}$ & $8422 \mathrm{~d}$ & $2880 \mathrm{~d}$ \\
\hline 75 & $9.65 \mathrm{~b}$ & $47 \mathrm{~b}$ & $42.51 \mathrm{~b}$ & $8850 \mathrm{c}$ & $3112 b$ \\
\hline 100 & $10.25 \mathrm{a}$ & $50 \mathrm{a}$ & $44.72 \mathrm{a}$ & $9290 \mathrm{~b}$ & $3445 \mathrm{a}$ \\
\hline 125 & $10.4 \mathrm{a}$ & $51 \mathrm{a}$ & $45.32 \mathrm{a}$ & 9639 a & 3551 a \\
\hline $\operatorname{LSD}(0.05)$ & 0.5 & 3 & 2.1 & 290.55 & 210.4 \\
\hline Control & 9.25 & 44 & 39.55 & 7906.65 & 2665 \\
\hline Rest & 9.91 & 47.7 & 43.18 & 9027.57 & 3328 \\
\hline Interaction & ns & Ns & ns & ns & $\mathrm{Ns}$ \\
\hline
\end{tabular}

Means sharing same letter(s) for a parameter in a column are statistically similar at $5 \%$ level of significance. ns $=$ non-significant 
Results showed that PM and P levels had a significant effect on spike length of wheat crop. Interaction of PM and P levels remained non-significant for spike length. Among levels of PM highest spike length was recorded for $2 \mathrm{t} \mathrm{ha}^{-1}$ of $\mathrm{PM}$ which was statistical similar with plots treated with PM at the rate of $1.5 \mathrm{t} \mathrm{ha}^{-1}$ while lowest spike length was recorded for $1 \mathrm{t} \mathrm{ha}^{-1} \mathrm{PM}$ treatment. This could be due to the availability of both micro and macro nutrients from PM which enhanced plant growth and spike length also. Our results are supported by findings of Shahid et al., (2015). Planned mean comparison of $\mathrm{P}$ levels showed that highest spike length was recorded for $125 \mathrm{~kg} \mathrm{ha}^{-1} \mathrm{P}$ treatment which was statistical similar with $100 \mathrm{~kg} \mathrm{ha}^{-1} \mathrm{P}$ treated plots while lowest spike length was recorded in plots fertilized with 50 $\mathrm{kg} \mathrm{ha}^{-1}$ P. According to Rahman et al., (2011), higher $\mathrm{P}$ level increases the availability of $\mathrm{P}$ and $\mathrm{Zn}$ that had considerably helpful effect on growth, yield and yield contributing parameters (Hao et al., 2009). Control vs rest showed significant variation for spike length of wheat crop.

\section{Grains spike $^{-1}$}

Different levels of poultry manure and phosphorus had cause significant variations in grains spike ${ }^{-1}$ as reported in Table 2. Interaction between $\mathrm{PM}$ and $\mathrm{P}$ levels was found non-significant for grains spike ${ }^{-1}$. When averaged across phosphorus levels, data indicated that highest grain spike $^{-1}$ was recorded for plots which were treated with $\mathrm{PM}$ at the rate of $2 \mathrm{t} \mathrm{ha}^{-1}$ while lowest grains spike $^{-1}$ was recorded for treatment of $1 \mathrm{t} \mathrm{ha}^{-1}$ of PM. The highest grains spike ${ }^{-1}$ due to PM might be due to greater rate of nitrogen which had not only increased the dry matter but also more partitioning toward the grains which consequently enhanced number of grains spike $^{-1}$. Incorporation of poultry manure into soil increased the soil fertility and ultimately the yield components of wheat. Our outcomes are supported by Shahid et al., (2015). Mean effect of $\mathrm{P}$ levels showed that highest grains spike $^{-1}$ was recorded for $125 \mathrm{~kg} \mathrm{ha}^{-1} \mathrm{P}$ level which was statistically at par with $100 \mathrm{~kg} \mathrm{ha}^{-1}$ $\mathrm{P}$ treatment while lowest grains spike ${ }^{-1}$ was recorded in plot which treated with $50 \mathrm{~kg} \mathrm{ha}^{-1}$ $\mathrm{P}$. Better root system development due to $\mathrm{P}$ application enhanced water and nutrients uptake which readily translocate towards developing sink might be the possible reasons for more grains per spike. Our findings are in line with those of Kaleem et al., (2009) who documented that grains spike $^{-1}$ significantly increased with the application of $P$. Significant difference was found in control vs rest for grains spike ${ }^{-1}$ of wheat crop.

\section{Thousand grains weight (g)}

Thousand grains weight of wheat crop as affected by different levels of PM and P are presented in Table 2. Statistical analysis of data revealed that both PM and P levels had a significant effect on thousand grains weight of wheat. Interaction of PM x $\mathrm{P}$ remained non-significant for thousand grains weight. Data across phosphorus levels showed that highest thousand grains weight was recorded in plots which were treated with $2 \mathrm{t} \mathrm{ha}^{-1} \mathrm{PM}$ while lowest thousand grains weight was recorded in plot treated with $1 \mathrm{tha}^{-1} \mathrm{PM}$. The increase in grain weight may be due to the fact that chicken manure supplies direct available nutrients (i.e. $\mathrm{N}$ ) to the plants and improvement of soil physical properties particularly in heavy clay soils result in heavy grains as reported by (Haris et al., 2002). After least significant difference test for $\mathrm{P}$ levels data showed that highest thousand grains weight was recorded in plot which received $\mathrm{P}$ at the rate of $125 \mathrm{~kg} \mathrm{ha}^{-1}$ which was statistically similar with plots fertilized with $100 \mathrm{~kg} \mathrm{ha}^{-1} \mathrm{P}$ while lowest thousand grains weight was recorded in plots which received $50 \mathrm{~kg} \mathrm{ha}^{-1} \mathrm{P}$. Kaleem et al., (2009) 
reported that application of $\mathrm{P}$ increased thousand grains weight in wheat crop. The increase in grain weight may be due to favorable effect of $\mathrm{P}$ on promoting vigorous plant growth. Also, P application improves root growth and health which in turn increases the absorption of nutrients and water from soil thus, increases grain weight. Control vs rest of wheat for thousand grains weight showed significant variation.

\section{Biological yield $\left(\mathrm{kg} \mathrm{ha}^{-1}\right)$}

Poultry manure and phosphorus levels significantly affected biological yield of wheat crop as reported in Table 2. Among levels of PM highest biological yield was recorded in plot which was treated with PM at the rate of $2 \mathrm{t} \mathrm{ha}^{-1}$ while lowest biological yield was recorded in plot which received $1 \mathrm{t}$ $\mathrm{ha}^{-1} \mathrm{PM}$. The reason for this increase might be the efficient use of all available resources for plant and roots because of low and continued supply of nutrients as well as more water absorption (Swarup and Yaduvanshi, 2000). Mean effect of PM indicated that highest biological yield was recorded in plot which received $125 \mathrm{~kg} \mathrm{ha}^{-1} \mathrm{P}$ which was statistically at par with $100 \mathrm{~kg} \mathrm{ha}^{-1} \mathrm{P}$ while lowest biological yield was recorded for $50 \mathrm{~kg} \mathrm{ha}^{-1} \mathrm{P}$ application. Phosphorous helps in development of strong and healthy root system which results in efficient uptake of essential nutrients required for maximum dry matter production. Absence of $\mathrm{P}$ in control plots did not develop healthy root system to facilitate better and timely absorption of nutrients and water thus led to lower dry matter production. Significant difference was recorded in control vs rest for biological yield of wheat crop.

\section{Grain yield (kg ha $\left.{ }^{-1}\right)$}

Data pertaining grain yield of wheat crop as influenced by different levels of poultry manure and phosphorus are presented in
Table 2. Interaction of treatments i.e. PM and $P$ levels remained non-significant for grain yield. When averaged across poultry manure, data indicated that highest grain yield was recorded in plot which was treated with $2 \mathrm{t}$ $\mathrm{ha}^{-1}$ of PM which was statistically not different with $1.5 \mathrm{t} \mathrm{ha}^{-1} \mathrm{PM}$ while lowest grain yield was recorded in plot which received $1 \mathrm{t}$ $\mathrm{ha}^{-1} \mathrm{PM}$. Increase in wheat grain yield with $\mathrm{PM}$ and $\mathrm{P}$ application can be attributed to more number of tillers and grains (Pedro et $a l ., 2011$ ) and more grain weight (Masoni et al., 2007). Organic materials (like PM) enhance nutrient use efficiency by slow releasing of nutrients and reducing their losses (Nevens and Reheul, 2003). The addition of organic fertilizer increases phosphorus mobilization and soil microbial activities; it might also contribute in improving nutrition as well as crop root system which all contribute to higher grain yield. Planned mean comparison for P levels showed that highest grain yield of wheat was recorded for $125 \mathrm{~kg} \mathrm{ha}^{-1} \mathrm{P}$ level which was statistically similar with $100 \mathrm{~kg} \mathrm{ha}^{-1} \mathrm{P}$ followed by plot which received $75 \mathrm{~kg} \mathrm{P}^{-1}$ while lowest grain yield was recorded in plots treated with $50 \mathrm{~kg} \mathrm{P} \mathrm{ha}{ }^{-1}$. This could be the result of reduced plant senescence rate at the grain filling stage and longer duration of green leaf area duration with the application of phosphorus as observed by Colomb et al., (2000). Also, P application enhanced root growth and developed strong root system to absorb more nutrients and water which resulted in more grain yield. Poor root system due to no $\mathrm{P}$ application in control plots might be the reason for lower grain yield. Our findings are similar to those of Mengel et al., (1996). Control vs rest showed significant result for grain yield of wheat crop. It can be concluded from experimental results that application of Poultry manure @ of 1.5 tons ha $^{-1}$ along with Phosphorus @ of $100 \mathrm{~kg} \mathrm{ha}^{-1}$ improved Phenological parameters, yield and yield components of wheat crop. 


\section{References}

Ahmed, N., M.T. Saleem, and I.T. Twyford. 1992. Phosphorus research in Pakistan-A review. Proc. Symposium on the role of phosphorus in crop production. NFDC, Islamabad. Pp. 59-92.

Amanullah, and Inamullah (2016b). Residual phosphorus and zinc influence wheat productivity under rice-wheat cropping system. Springer Plus 5:255.

Amanullah, and Inamullah (2016b). Residual phosphorus and zinc influence wheat productivity under rice-wheat cropping system. Springer Plus 5:255.

Amanullah, and Khalid, S. (2015). Phenology, growth and biomass yield response of maize (Zea mays L.) to integrated use of animal manures and phosphorus application with and without phosphate solubilizing bacteria. J. Microb. Biochem. Technol. 7, 439-444.

Amanullah, and Khan, M.W. (2010). Interactive effects of potassium and phosphorus application on phenology and grain yield of sunflower in Northwest Pakistan. Pedosphere 20, 674-680.

Amanullah, and Stewart, B.A. (2013).Dry matter partitioning, growth analysis and water use efficiency response of oats (Avena sativa L.) to excessive nitrogen and phosphorus application. J. Agric. Sci. Technol. 15, 479-489.

Amanullah, Majidullah, and Khan, I. (2014).Pheno-morphological traits of mungbean as influenced by phosphorous and tillage under irrigated and un- irrigated conditions. Pure Appl. Biol. 3, 55-59.

Brady, C. and R.R Weils. 1999. Nature and properties of soil twelfth edition, Prentice Hall, New Delhi. Pp. 74-114.

Bugbee, H., and E. Khera. 1999. Response of phosphorous to different temperature. $J$. Environ. Qual. 28(2): 431-438.

Colomb, B., J. R. Kiniry and P. Deback. 2000. Effect of soil phosphorus on leaf development and senescence dynamics of field grown maize. Agron. J. 92: 428-435
Colomb, B., J. R. Kiniry and P. Deback. 2000. Effect of soil phosphorus on leaf development and senescence dynamics of field grown maize. Agron. J. 92: 428-435

Dannis, D.L., D.L. Karlen, D.B. Jaynes, T.C. Kaspar, J.L. Hatfield, T.S. Colvin and C.A Cambardella. 2002. Nitrogen management strategies to reduce nitrate leaching in Tile drained mid-western soils. Agron.J. 94: 153171.

Deksissa, T., I. Short, and J. Allen. 2008. Effect of soil amendment with compost on growth and water use efficiency of Amaranth. In: Proceedings of the UCOWR/NIWR annual conference: International water resources: challenges for the 21st century and water resources education, July 22-24, Durham, NC.

Delgado, A., I. Uceda, L. Andreu and S. Kassem. 2002. Fertilizer phosphorus recovery from gypsum-amended reclaimed calcareous marsh soils. Arid Land Research and Management 16: 319-334.

Dinnes, D.L., Karlen, D.B. Jayes, T.C. Kaspar, J.L. Hatfield, T.S. Colvin, and C.A. Cambaredella. 2002. Nitrogen management strategies to reduce nitrate leaching in tiledrained Midwestren soils. J. Agron. 94: 153171.

Egerszegi, E. 1990. Effect of sewage sludge and compost applied to the soil on some physical and chemical properties. J. Environ. Qual. 15:122-127.

Enujeke, E.C. 2013.Effects of poultry manure on growth and yield of improved maize in Asaba area of delta state, Nigeria. J. Agri. Vet. Sci.4: 24-30.

Fageria, N.K., and Baligar, V.C. (2005). Nutrient availability, in Encyclopedia of Soils in the Environment, ed D.Hillel (San Diego, CA: Elsevier), 63-71.

Fageria, N.K., Slaton, N.A., and Baligar, V.C. (2003).Nutrient management for improving low land rice productivity and sustainability. Adv. Agron. 80, 63-152.

Garg, S., and G.S. Bahla. 2008. Phosphorus availability to maize as influenced by organic manures and fertilizer $\mathrm{P}$ associated 
phosphatase activity in soils. Biores. Technol. 99(13): 5773-5777.

Gosh PK, Ramesh KK, Bandyopadhyay AK, Tripathi, KM Hati, et al., (2004) Comparative effectiveness of cattle manure, poultry manure. Phosphor compost and fertilizer- NPK on three cropping systems in vertical of semi-arid tropics. Bioresour Technol 95(1): 85-93.

Harris F (2002) Management of manure in farming systems in semi-arid West Africa. ExplAgric 38: 131-148.

Huang, B., W.Z. Sun, Y.Z. Hao, J. Hu, R. Yang, Z. Zou, F. Ding, and J. Su. 2007. Temporal and spatial variability of soil organic matter and total nitrogen in an agricultural ecosystem as affected by farming practices. Geoderma. 139: 336-345.

Ibrahim, M, A. Hassan, M. Iqbal, E. E. Valeem. 2008. Response of Wheat Growth and Yield to Various Levels of Compost and Organic Manure. Pak. J. Bot. 40(5): 2135-2141.

Jan, M.T., P. Shah, P.A. Hollington, M. J. Khan, and Q. Sohail. 2009. Agriculture Research: Design and Analysis, A monograph. Agric. Univ. Pesh. Pak

Johnston, A.M., S.S. Malhi, J.J. Schoenau and S.W. Exner. 1999. Nutrient and biomass accumulation of major crops. Research Report Canadian Fertility Institute, Ottawa

Kaleem, S., M. Ansar, M. A. Ali, A. Sher, G. Ahmad and M. Rashid. 2009. Effect of phosphorus on the yield and yield components ofwheat variety "Inqlab-91" under rainfed conditions. Sarhad J. Agric.25: 21-24.

Khalil, S.K., Khan, S., Rahman, A., Khan, A. Z. and khalil, I.H., Amanullah (2010). Seed priming and $\mathrm{P}$ application enhance penology, dry matter production of wheat. Pak. J. Bot. 42, 1849-1856.

Masoni, A., L. Ercoli, M. Mariotti and I. Arduini. 2007. Post-anthesis accumulation and remobilization of dry matter, nitrogen and phosphorus in durum wheat as affected by soil type. European Journal of Agronomy26: 179-186.

Masoni, A., L. Ercoli, M. Mariotti and I. Arduini. 2007. Post-anthesis accumulation and remobilization of dry matter, nitrogen and phosphorus in durum wheat as affected by soil type. European Journal of Agronomy 26: 179-186

Mengel, K and E. A. Kirkby. Principles of Plant Nutrition. Panimo Publishing Corporation, New Delhi, India. 1996.

Mengel, K., and E. A. Kirkby. Principles of Plant Nutrition. Panimo Publishing Corporation, New Delhi, India. 1996.

Naeem, M., F. Khan, and W. Ahmad. 2009. Effect of farmyard manure, mineral fertilizer and mung bean residues on some microbiological properties of eroded soil is district Swat. Soil Environ. 28(2): 162-169.

Nevens, F. and D. Reheul. 2003. The application of vegetable, fruit and garden waste (VFG) compost in addition to cattle slurry in a silage maize monoculture: nitrogen availability and use. Europ. $J$. Agron. 19: 189-203.

Nevens, F. and D. Reheul. 2003. The application of vegetable, fruit and garden waste (VFG) compost in addition to cattle slurry in a silage maize monoculture: nitrogen availability and use. Europ. $J$. Agron. 19: 189-203.

Opala, P.A., Othieno, E.O., Okalebo, J.R., and Kisinyo, P.O. 2009. Effect of combining organic materials with inorganic phosphorus sources on maize yield and financial benefits in Western Kenya. Exper. Agric. 46:23-34.

Osava, M. 2007. Farming faces phosphate shortfall. Energy Bulletin.15 Oct.2007:1

Paul, G.C, M.A. Mannan. 2006. Integrated nutrient management in sugarcane to enhance sugar productivity. In: Proceedings, International symposium on technologies to improve sugar productivity in developing countries, Gullin. 108-121.

Pedro, A., R. Savin, D.Z. Habash and G.A. Slafer. 2011. Physiological attributes associated with yield and stability in selected lines of a durum wheat population. Euphytica180: 195-208.

Pedro, A., R. Savin, D.Z. Habash and G.A. Slafer. 2011. Physiological attributes associated with yield and stability in selected 
lines of a durum wheat population. Euphytica180: 195-208.

Rahman, K.M. M. Chowdhury, M.A.K., Sharmeen, F., Sarkar, A., Hye, M.A., and Biswas, G.C. (2011). Effect of zinc and phosphorus on yield of Oryza sativa (cv. br11). Bangladesh Res. Pub. J. 5:351-358

Rashid, M.T., M. Yaseen, and M.S. Zia. 1994. Phosphorus availability to wheat in three calcareous soils of rice tract. Proc. 4th National Congress of Soil Science, Islamabad.265-270.

Rasool, R., S.S. Kuka, and G.S. Hira. 2007. Soil physical fertility and crop performance as affected by long-term application of FYM and inorganic fertilizers in rice-wheat system. Soil Tillage Res. 96: 64-72.

Rast, H., Liedgens, M., Sangakkara, U.R., and Stamp, P. (2010). Early growth of crotalaria (Crotalaria juncea), Tithoniat Tithonia diversifoliay; and maize (Zea mays) as affected by soil fertility and phosphorus fertilizer under pot and field conditions. Comm. Soil Sci. Plant Anal.41:1655-1664.

Rautaray, S.K., B.C. Ghosh, and B.N. Mittra. 2003. Effect of fly ash, organic wastes and chemical fertilizers on yield, nutrient uptake, heavy metal content and residual fertility in a rice-mustard cropping sequence under acid lateritic soils. Bioresource Technol. 90: 275283.

Rehman, O., S.M. Mehdi, A.M. Ranjha, and M. Sarfaraz. 2007. Phosphorous requirement of cereal crops and fertility buildup factor in a typic. J. Biol. Sci. 7(7): 1072-1081.

Saleem, N., M. Adnan, N.A. Khan, S. Zaheer, F. Jalal, M. Amin, W.M. Khan, M. Arif, I. Rahman, M. Ibrahim, Y. Jamal, S.R.A. Shah, K. Junaid and M. Ali, 2015. Dual purpose canola: grazing and grains options. Pak. J. Weed Sci. Res, 21(2): 295-304.

Sarwar, N. M. Maqsood, K. Mubeen, M. Shehzad, M.S. Bhullar, R. Qamar and N. Aqbar. 2010. Effect of different levels of irrigation on yield and yield components of wheat cultivars. Pak. J. Agric. Sci. 47: 371374.

Shahid, M., M. Farrukh. Saleem, H.Z. Khan, M. A. Wahid and M. Sarwar.2015.Improving wheat (Triticum aestivum L.) yield and quality by integration of urea with poultry manure. Soil Environ. 34(2): 148-155.

Sharpley, A.N., and Smith, S.J. 1991. Nitrogen and phosphorus forms in soil receiving manure. Soil Science. 159: 253-258.

Shenoy, V.V., and G.M. Kalagudi. 2005. Enhancing plant phosphorous use efficiency for sustainable cropping. Biotech. Adv. 23:501-513.

Sims, J.T., and D.C. Wolf. 1994. Poultry waste management: Agricultural and environmental issues. Adv. Agron. 50: 1-83.

Swarup, A. and N.P.S. Yaduvanshi. 2000. Effect of Integrated nutrient management on soil properties and yield of rice in Alkali soils. J. Indian Soc. Soil Sci. 48: 279-282.

Swarup, A. and N.P.S. Yaduvanshi. 2000. Effect of Integrated nutrient management on soil.

Tahir, M., Ali. M. Anjum. S. Iqbal, and M. Yamin. Evaluation of the Effect of Use of N.P. Fertilizer in Different Ratios on the Yield of Wheat (Triticum aestivum) Crop. Pak. J. Life Soc. Sci. 2(2): 145-147. 2004.

Twyford, I.T. 1994. Fertilizer use and crop yields. Proc. 4th National Congress of soil science, Islamabad. Pp. 47-71.

\section{How to cite this article:}

Muhammad Faheem Jan, Muhammad Dawood Ahmadzai, Waqas Liaqat, Haseeb Ahmad and Wazir Rehan. 2018. Effect of Poultry Manure and Phosphorous on Phenology, Yield and Yield Components of Wheat. Int.J.Curr.Microbiol.App.Sci. 7(05): 3751-3760.

doi: https://doi.org/10.20546/ijcmas.2018.704.422 